Reviu Akuntansi dan Bisnis Indonesia, Vol. 4 No. 1, Hlm: 79-92, Juli 2020

Website: http://journal.umy.ac.id/index.php/rab

\title{
Pengaruh Non-Performing Financing Pembiayaan Murabahah, Mudharabah, dan Musyarakah terhadap Profitabilitas Bank Umum Syariah di Indonesia
}

\author{
Aiman $^{1 *}$, Bambang Sutrisno ${ }^{1}$ \\ 'Program Studi Manajemen Universitas Muhammadiyah Jakarta
}

I N F O A R T I K E L

\section{Kata Kunci:}

Profitabilitas, Non-

Performing Financing,

Murabahah, Mudharabah,

Musyarakah

Jenis Artikel:

Penelitian Empiris

Korespondensi:

aimanbaj@gmail.com
A B S T R A K

Latar Belakang:

Profitabilitas merupakan ukuran kemampuan suatu perusahaan dalam mendapatkan laba. Perolehan laba akan berpengaruh pada seberapa besar kemampuan bank dalam mengelola dana investasi dengan menggunakan aset produktifnya. Di tengah meningkatnya kesadaran masyarakat dalam penggunaan industri keuangan yang berprinsip syariah, akan tetapi perbankan syariah di Indonesia memiliki tantangan terkait pembiayaan bermasalah atau dikenal dengan non-performing financing yang masih relatif tinggi.

Tujuan:

Penelitian ini bertujuan untuk menganalisis pengaruh non-performing financing (NPF) pembiayaan murabahah, mudharabah, dan musyarakah terhadap profitabilitas bank umum syariah di Indonesia periode 20142018. Penelitian ini merupakan jenis penelitian kuantitatif dengan sifat asosiatif. Sampel penelitian sebanyak 7 (tujuh) bank umum syariah dengan menggunakan teknik purposive sampling.

Metode Penelitian:

Teknik analisis data yang digunakan dalam penelitian adalah regresi data panel dengan model common effect.

\section{Hasil Penelitian:}

Hasil penelitian menyimpulkan bahwa secara parsial NPF pembiayaan murabahah, NPF pembiayaan mudharabah, dan NPF pembiayaan musyarakah masing-masing berpengaruh negatif dan signifikan terhadap profitabilitas bank umum syariah di Indonesia. Temuan ini tetap konsisten walaupun menggunakan proksi profitabilitas yang lain.

\section{Keterbatasan Penelitian:}

Dalam penelitian ini memiliki beberapa keterbatasan, diantaranya adalah periode penelitian yang digunakan hanya 5 (lima) tahun yaitu dari tahun 2014 sampai 2018 dan variabel yang digunakan dalam penelitian adalah NPF pembiayaan murabahah, NPF pembiayaan mudharabah, dan NPF pembiayaan musyarakah.

Keaslian/Novetly Penelitian:

Penelitian ini fokus pada NPF pembiayaan murabahah, NPF pembiayaan mudharabah, dan NPF pembiayaan musyarakah. Peneltian sebelumnya hanya focus pada satu pembiayaan saja, dan belum ada penelitian yang menggunakan dengan beberapa pembiayaan sebagai perbandingan. 


\section{PENDAHULUAN}

Bank adalah institusi yang penting untuk membantu meningkatkan pertumbuhan ekonomi negara. Fungsi suatu bank bertujuan untuk mendorong peningkatan derajat kehidupan banyak orang. Oleh sebab itu bank dikenal juga sebagai perantara keuangan (financial intermediary). Di Indonesia menganut sistem perbankan dengan menggunakan sistem dual-perbankan diantaranya bank syariah dan bank konvensional. Dalam menjalankan operasional kegiatan bisnisnya masingmasing, kedua bank tersebut memiliki perbedaan yang terletak pada prinsip-prinsip yang digunakan di setiap prosesnya. Bank syariah melakukan kegiatan khususnya dengan memberikan jasa yang berdasarkan prinsip-prinsip syariah pada alur pembayarannya. Oleh karena itu, setiap proses bisnisnya harus memegang teguh pada prinsip Islam, serta dalam prosesnya nasabah tidak dibebankan untuk membayarkan bunga. Bank syariah hanya menerima imbalannya dari setiap pembayaran yang dilakukan oleh nasabah sesuai dengan akad atau perjanjian antara bank dan nasabah.

Pada tahun 1992, Bank Muamalat Indonesia didirikan sebagai bank komersial syariah pertama serta sekaligus sebagai pelopor lahirnya perbankan Islam pertama di Indonesia sesuai dengan ditetapkannya UU No.7/1992 tentang perbankan. Pada tahun 1999 diikuti dengan lahirnya Bank Syariah Mandiri dan setelah itu di tahun 2004 berdirinya Bank Mega Syariah. Perkembangan tersebut melahirkan banyaknya jaringan kantor-kantor perbankan syariah yang tersebar luas di seluruh Indonesia (Arifin, 2012:10).

Di tengah berkembangnya bank syariah di Indonesia dengan meningkatnya kesadaran masyarakat terhadap industri keuangan yang berprinsip syariah tersebut, akan tetapi perbankan syariah di Indonesia masih menghadapi tantangan yang terkait masalah pembiayaan bermasalah atau biasa disebut Non-Performing Financing (NPF) yang relatif tinggi. Tingkat NPF yang tinggi menunjukkan kesehatan bank yang semakin rendah karena hal ini mengindikasikan banyak terjadinya pembiayaan bermasalah dalam kegiatan operasional bank (Aryani dkk., 2016).

Tabel 1

Data Nilai NPF Bank Umum Syariah di Indonesia Tahun 2014-2018

\begin{tabular}{cc}
\hline Tahun & NPF $(\%)$ \\
\hline 2014 & 3,38 \\
2015 & 3,19 \\
2016 & 2,17 \\
2017 & 2,57 \\
2018 & 2,46 \\
\hline
\end{tabular}

Sumber: Data Statistik Perbankan OJK

Tingkat nilai NPF bank umum syariah pada Tabel 1 mengalami fluktuatif. NPF tertinggi terjadi pada tahun 2014, sedangkan NPF terendah terjadi pada tahun 2016. Tingginya NPF mengindikasikan bahwa terjadi pembiayaan macet dalam jumlah besar yang pada akhirnya dapat mempengaruhi kinerja bank umum syariah. Hal ini tentu perlu mendapat perhatian khusus dari OJK sebagai pengawas bank syariah.

Profitabilitas merupakan acuan yang sangat penting bagi suatu perusahaan atau bank, yaitu indikator dalam melihat tingkat efisiennya bank untuk memperoleh keuntungan. Parameter untuk menghitung profitabilitas perbankan dilihat dari return on assets (ROA). Muhamad (2015, hal. 254) menjelaskan bahwa ROA yaitu rasio untuk dapat melihat seberapa besar kemampuan bank dalam mengelola dana investasinya dengan menggunakan seluruh aset produktif yang ada untuk memperoleh keuntungan.

Dengan peningkatan kualitas dalam pendistribusian aset produktif merupakan upaya untuk meningkatkan profitabilitas. Pendistribusian aset produktif yang dilakukan oleh perbankan syariah yaitu pembiayaan yang ditawarkan kepada masyarakat dalam memenuhi kebutuhan, diantaranya pembiayaan berdasarkan prinsip akad bagi hasil serta jual beli. Perbankan syariah mengaplikasikan akad jual beli ke dalam bentuk pembiayaan dibagi menjadi 3 (tiga) skema, diantaranya adalah 
murabahah, salam, istishna (Widya dkk, 2015). Prinsip bagi hasil adalah bentuk skema dalam pembiayaan pada akad mudharabah dan musyarakah yang diterapkan oleh bank (Rifqi, 2010:40). Pendistribusian pembiayaan-pembiayaan yang dilakukan oleh perbankan syariah kepada masyarakat berpotensi terjadinya Non-Performing Financing (pembiayaan bermasalah).

Beberapa penelitian terkait Non-Performing Financing (pembiayaan bermasalah) telah dikaji oleh para peneliti. Hadiyati dan Riski (2013) menemukan bahwa NPF pembiayaan mudharabah berpengaruh negatif terhadap profitabilitas Bank Muamalat Indonesia, namun NPF pembiayaan musyarakah tidak berpengaruh terhadap profitabilitas. Widya dkk. (2015) menyimpulkan bahwa NPF pembiayaan murabahah dan mudharabah tidak berpengaruh signifikan terhadap profitabilitas bank umum syariah, sedangkan NPF pembiayaan musyarakah berpengaruh signifikan terhadap profitabilitas bank umum syariah. Yulianah dan Komariah (2017) menemukan bahwa variabel risiko pembiayaan murabahah berpengaruh signifikan terhadap profitabilitas, sedangkan risiko pembiayaan mudharabah dan musyarakah tidak berpengaruh terhadap profitabilitas bank umum syariah periode 2011-2015.

Berdasarkan latar belakang masalah yang telah dijabarkan sebelumnya, penelitian ini bertujuan untuk menguji pengaruh NPF pembiayaan murabahah, NPF pembiayaan mudharabah, dan NPF pembiayaan musyarakah terhadap profitabilitas bank umum syariah di Indonesia. Penelitian ini berbeda dengan penelitian sebelumnya, dimana peneliti menggunakan data bank umum syariah yang lebih lengkap, periode pengamatan yang digunakan lebih terkini yaitu tahun 2014-2018, serta pembuktian uji ketangguhan pada proksi profitabilitas terhadap hasil penelitian.

\section{TINJAUAN LITERATUR DAN PERUMUSAN HIPOTESIS}

\section{Productive Theory of Credit}

Teori ini menjelaskan mengenai dasar-dasar yang digunakan manajemen untuk mengambil keputusan sumber pendanaan bagi perusahaan (Sudiyatno dan Suroso, 2010). Productive theory of credit (Commercial Loan Theory) menekankan bahwa likuiditas bank akan terjamin apabila aktiva produktif disusun dari kredit jangka pendek yang mudah dicairkan selama bisnis dalam kondisi normal.

Teori tersebut sesuai dengan pokok permasalahan yang dianalisis dalam penelitian ini, karena berhubungan dengan teori permodalan yang sudah seharusnya diperhatikan oleh dunia perbankan dalam hal kecukupan modal. Secara konseptual, standar kecukupan modal diperlukan agar dapat menjamin keberlanjutan perbankan.

Teori ini menyatakan secara spesifik bahwa bank-bank akan memberikan pembiayaannya dalam bentuk kredit jangka pendek melalui pembayaran Kembali (angsuran) atas kredit tersebut sebagai sumber likuiditas. Pembayaran Kembali untuk kredit ini adalah melalui perputaran kas dan modal kerja yang telah dibelanjai melalui kredit ini.

\section{Profitabilitas}

Profitabilitas merupakan suatu acuan yang paling dibutuhkan pada perbankan, lantaran menjadi indikator yang dapat menghitung efisiensi perbankan untuk mendapatkan laba dari aset yang ada. Gitman (2009, hal. 65) menjelaskan bahwa profitabilitas adalah hubungan antara pendapatan dan biaya yang diperoleh dalam menggunakan seluruh aset perusahaan, baik aset lancar dan aset tetap. Bank yang sehat adalah bank yang diukur secara profitabilitas yang terus meningkat diatas standar yang diterapkan (Suryani, 2011:55).

Ukuran menilai kemampuan perusahaan dalam menghasilkan laba pada periode tertentu menggunakan rasio profitabilitas (Huriyah, 2014:153). Tujuan dari rasio ini yaitu biasanya digunakan oleh perbankan untuk menganalisis seberapa besar tingkat keberhasilan kinerja bank dan juga dapat mengetahui besar atau kecilnya perolehan laba yang didapat. Tingkat rasio 
profitabilitas yang lebih baik menunjukkan tingginya kemampuan perbankan dalam memperoleh keuntungan (Irham, 2013:80).

\section{Pembiayaan}

Menurut Undang-Undang No. 10 tahun 1998 pasal 1 ayat 12 tentang perbankan menyatakan bahwa pembiayaan berdasarkan prinsip syariah adalah penyediaan uang atau tagihan yang dapat dipersamakan dengan itu, berdasarkan persetujuan atau kesepakatan antara bank dengan pihak lain yang mewajibkan pihak yang dibiayai untuk mengembalikan uang atau tagihan setelah jangka waktu tertentu dengan imbalan bagi hasil.

Ikatan Bankir Indonesia (2018, hal. 202) menjelaskan bahwa pembiayaan di bank syariah pada dasarnya adalah sebuah kesepakatan antara nasabah dan bank untuk memberikan dananya kepada pihak yang membutuhkan dana dan membiayai seluruh kegiatan usahanya. Pembiayaan dari produk perbankan syariah tidak terjadi penambahan kembalian pada pokok pinjaman dalam bentuk bunga. Bank syariah tidak menjadikan bunga sebagai instrumen operasional bisnis. Kegiatan menyalurkan pembiayaan dari bank syariah dilandasi dengan Al-Qur'an dan Hadits.

Dalam mengontrol dan mengantisipasi risiko pembiayaan pada perbankan syariah dapat dilihat dari kualitas pembiayaan dari perbankan tersebut. Kualitas pembiayaan (Kolektabilitas) merupakan tingkat pengembalian dana terhadap suatu pembiayaan yang dilakukan nasabah. Menentukan kualitas suatu pembiayaan dapat dilihat dari prospek bisnis atau kinerja bisnis yang sedang dijalankan oleh nasabah dalam proses pembiayaan tersebut. Muhamad (2015, hal. 343) menjelaskan bahwa ada 5 (lima) bagian dari kualitas pembiayaan seperti lancar, dalam perhatian khusus, kurang lancar, diragukan, dan macet.

\section{Pembiayaan Murabahah}

Menurut Karim (2016,hal. 113), mendefinisikan murabahah adalah akad jual beli antara penjual dan pembeli pada suatu barang menyebutkan harga perolehan dengan margin yang ditambah sesuai perjanjian awal. Pembiayaan tersebut dapat diartikan suatu kontrak jual beli antara nasabah dan bank, pada akad ini hasil laba yang didapat biasanya ditentukan oleh bank atau disebut juga dengan required rate of profit. Margin (keuntungan) yang diperoleh, besar kecil nilainya dapat dilihat dari rupiah serta dengan hasil dari persentase harga beli.

Pada pembiayaan ini, dimana penjual wajib menginformasikan harga pokok suatu barang serta memberitahukan jumlah laba (margin) yang ditambahkan ke dalam biaya tersebut kepada pembeli. Kesimpulan dari pengertian di atas, bahwa pembiayaan pada akad murabahah dapat diartikan sebagai transaksi yang dilakukan dalam bentuk jual beli antara nasabah dan bank.

Prabowo (2012, hal. 34-35) menjelaskan bahwa terdapat dua jenis pembiayaan akad murabahah yang ada di perbankan syariah, diantaranya adalah murabahah tanpa pesanan dan murabahah berdasarkan pesanan. Murabahah tanpa pesanan yaitu terdapat pesanan atau tidaknya atau dengan kata lain adanya pembeli atau tidaknya, dimana posisi bank sebagai penjual ( $b a$ ’). persediaan barang pada model ini tidak mempengaruhi adanya pesanan atau tidak. Sedangkan murabahah berdasarkan pesanan adalah transaksi yang terdiri dari dua orang atau lebih yang bernegoisasi dan bersepakat dalam menjalankan atas kesepakatan yang telah disepakati, Adapun proses dari model ini nasabah membeli suatu aset dengan cara memesan kepada bank dan nasabah dapat memiliki aset tersebut secara sah.

\section{Pembiayaan Mudharabah}

Muhamad (2015, hal. 41) mengemukakan bahwa mudharabah adalah transaksi pemesanan dana dari pemilik dana (shohibul maah) kepada pengelola dana (mudharib) untuk melakukan kegiatan usaha sesuai dengan prinsip syariah, dengan pembagian hasil usaha antara kedua belah pihak berdasarkan nisbah yang telah disepakati sebelumnya. 
Pada akad pembiayaan ini yaitu bentuk perjanjian investasi atau transaksi berbasis investasi untuk kegiatan bisnis tertentu. Dalam hal ini, menjalin kerja sama antara bank dan nasabah yang telah sepakat dalam kegiatan bisnis/proyek. Posisi bank dalam pembiayaan ini sebagai yang menyediakan modal/dana (investor) atau disebut dengan istilah shohibul maal, dan posisi nasabah disini sebagai yang memberikan keahlian/keterampilan untuk mengelola proyek atau disebut dengan istilah mudharib.

Pembiayaan akad mudharabah ini dapat dibedakan menjadi dua jenis yaitu mudharabah muthlaqah dan mudharabah muqayyadah (Muhamad, 2015:41). Mudharabah muthlaqah adalah kerja sama antara pemilik dana dengan pengelola dana, dimana tidak membatasi ruang lingkup dari kegiatan bisnis secara rinci. Sedangkan definisi mudharabah muqayyadah kebalikan dari jenis mudharabah sebelumnya, yaitu membatasi ruang lingkup kegiatan bisnisnya secara spesifikasi sesuai dengan permintaan pemilik dana, diantaranya jenis usaha, waktu, dan bidang usaha. Perbedaan dari dua jenis akad pembiayaan mudharabah dapat dilihat dari sisi wilayah kegiatan bisnisnya.

\section{Pembiayaan Musyarakah}

Pembiayaan pada akad mudharabah dan musyarakah sama-sama pembiayaan yang berbasis bagi hasil. Ikatan Bankir Indonesia (2018, hal. 215) mendefinisikan akad pembiayaan musyarakah yaitu menjalin kerja sama antara bank sebagai yang menanamkan modalnya dan nasabah yang menerima dana tersebut atau sebagai pengelola dana dari suatu proyek bisnis, dimana pembagian hasil dari kegiatan tersebut sesuai dengan kesepakatan sebelumnya dalam bentuk porsi (nisbah) yang telah ditentukan. Contoh akad pembiayaan musyarakah diantaranya pembiayaan sindikasi, modal kerja, dan investasi.

Pembiayaan dengan akad musyarakah, yaitu kerjasama antara nasabah dan bank pada suatu kegiatan bisnis, peran bank disini selaku pemilik modal atau yang menyediakan dana, sedangkan peran nasabah selaku pengelola dana dan juga sebgai pemodal atau yang menyediakan modal untuk mengerjakan kegiatan usaha tersebut. Artinya dalam pembiayaan ini nasabah tidak hanya selaku pengelola saja, akan tetapi juga selaku penanam modal.

Berdasarkan ulama fiqih dalam bukunya Nurhayati dan Wasilah (2013, hal. 151) menjelaskan bahwa jenis pembiayaan berupa akad musyarakah dibagi menjadi dua yaitu syirkah al-milk dan syirkah al-'uqud. Yang dimaksud dengan syirkah al-milk yaitu syarat keberadaannya diakui, jika kepemilikan atas kekayaan diperoleh dari dua orang atau lebih secara bersama-sama dan model ini bersifat memaksa, contohnya; harta warisan yang didapatkan dari ahli warisnya dan hibah sebidang tanah. Sedangkan syirkah al-uqud yaitu terciptanya perjanjian dalam bentuk kemitraan dalam menjalin kerjasama dengan menggabungkan harta guna (dana/modal) untuk melakukan suatu proyek bisnis/usaha, dimana pembagian hasilnya baik berupa laba maupun rugi ditanggung antara pihak yang bersangkutan sesuai dengan porsi modalnya masing-masing.

\section{Non-Performing Financing (Pembiayaan Bermasalah)}

Pembiayaan bermasalah (Non-Performing Financing) merupakan indikator utama dalam menilai kinerja pada suatu bank. Ikatan Bankir Indonesia (2018, hal. 223) menjelaskan bahwa pembiayaan dengan kategori kolektabilitasnya Kurang Lancar, Diragukan, dan Macet dapat disebut sebagai pembiayaan dengan kualitas buruk dan digolongkan sebagai pembiayaan bermasalah (Non-Performing Financing). NPF adalah pembiayaan yang terjadi ketika pihak debitur karena berbagai alasan, tidak dapat memenuhi kewajibannya untuk mengembalikan dana pembiayaan (pinjaman).

Mudrajad dan Suhardjono (2011, hal. 420) menjelaskan bahwa NPF adalah kondisi dimana nasabah tidak mampu membayarkan kewajibannya kepada bank secara keseluruhan atau sebagian sebagaimana yang telah disepakati di awal. Jika semakin kecil NPF maka bank tersebut dapat menghasilkan keuntungan, sebaliknya jika NPF semakin besar maka bank tersebut dapat meyebabkan kerugian dari tingkat pengembalian. 
NPF juga dikenal sebagai NPL (non performing loan) yang digunakan bank konvensional adalah rasio keuangan yang terkait dengan risiko kredit yang terjadi. NPF sendiri merupakan kemampuan bank yang menunjukkan pengelolaan dengan cara meminimalisir sekecil mungkin setiap pembiayaan bermasalah yang telah disalurkan bank.

\section{Pengaruh NPF Pembiayaan Murabahah terhadap Profitabilitas}

NPF pembiayaan murabahah dapat dihitung dengan cara yaitu membagikan total pembiayaan murabahah yang bermasalah dengan keseluruhan pembiayaan murabahah (Fauzan, 2012). Risiko pembiayaan ini sangat berpengaruh terhadap tingkat keuntungan suatu bank syariah, dimana pembiayaan murabahah ini adalah pembiayaan yang paling sering digunakan oleh masyarakat. Karena naik turunnya risiko pembiayaan murabahah berpengaruh terhadap profitabilitas.

Dari penjabaran di atas menjelaskan bahwa tingkat NPF yang tinggi akan mempengaruhi kualitas dari suatu bank yang menggambarkan pada Kesehatan bank yang tidak cukup baik. Tingginya pembiayaan bermasalah atau NPF kemungkinan akan menurunkan besaran pendapatan yang dihasilkan. Penurunan pendapatan ini akan mengakibatkan dari hasil laba yang diperoleh bank syariah dan berdampak pada besaran tingkat profitabilitas suatu bank syariah yang dapat dilihat dari return on assets (ROA). Yulianah dan Komariah (2017), menunjukkan hasil penelitian bahwa risiko pembiayaan murabahah berpengaruh terhadap profitabilitas. Berdasarkan penjelasan sebelumnya, hipotesis yang diajukan adalah:

\section{$\boldsymbol{H}_{i}: \mathbf{N P F}$ pembiayaan murabahah berpengaruh terhadap profitabilitas.}

\section{Pengaruh Pembiayaan Mudharabah terhadap Profitabilitas}

Pada pembiayaan mudharabah keuntungan yang dapat dibagi sesuai dengan kesepakatan dan kerugian ditanggung dengan pihak penyedia modal, tetapi bukan kerugian atas kelalaian pengelola (Yulianah dan Komariah: 2017). Non-Performing Financing pembiayaan mudharabah dapat dihitung dengan cara total pembiayaan mudharabah bermasalah dibagi total keseluruhan pembiayaan mudharabah.

Hadiyati dan Riski (2013) menemukan bahwa NPF pembiayaan mudharabah berpengaruh negatif terhadap profitabilitas. Berdasarkan uraian yang telah dijelaskan, hipotesis yang diajukan adalah:

$\boldsymbol{H}_{2}: \mathbf{N P F}$ pembiayaan mudharabah berpengaruh terhadap profitabilitas.

\section{Pengaruh NPF Pembiayaan Musyarakah terhadap Profitabilitas}

Risiko pembiayaan musyarakah sebagaimana dapat diketahui bahwa kualitas aset produktif dalam bentuk pembiayaan dapat diukur dengan mengetahui besarnya credit risk (kredit macet), yaitu dapat dihitung dengan perbandingan besarnya jumlah risiko pembiayaan musyarakah dengan total pembiayaan musyarakah (Fauzan, 2012).

Hadiyati dan Riski (2013) menunjukkan bahwa NPF pembiayaan musyarakah tidak berpengaruh terhadap profitabilitas. Berdasarkan uraian yang telah dijelaskan, hipotesis yang diajukan adalah:

\section{$\mathrm{H}_{3}$ : NPF pembiayaan musyarakah berpengaruh terhadap profitabilitas.}




\section{Kerangka Konseptual}

Berdasarkan hasil telaah pustaka, baik secara teoritis maupun empiris, penelitian ini menggunakan kerangka pemikiran sebagai berikut:

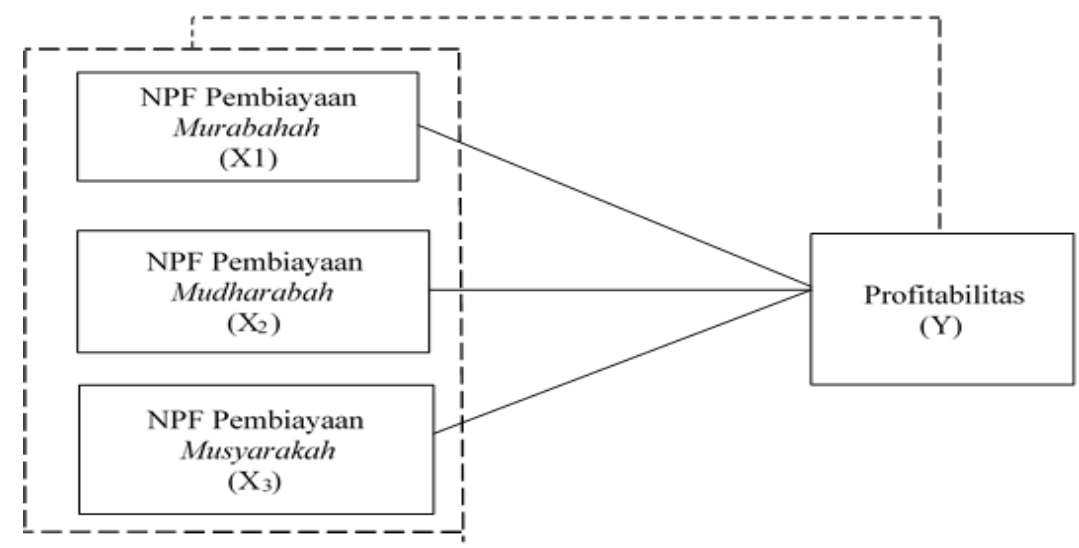

Gambar 1 Kerangka Konseptual

\section{METODE PENELITIAN}

\section{Rancangan Penelitian}

Jenis penelitian yang digunakan dalam penelitian ini adalah jenis penelitian kuantitatif, yaitu data yang diperoleh dalam bentuk angka dan dianalisis menggunakan statistik. Penelitian ini menggunakan sifat asosiatif yang bertujuan untuk menguji pengaruh suatu variabel terhadap variabel yang lain.

\section{Sumber Data, Populasi, dan Sampel}

Penelitian ini menggunakan sumber data sekunder berupa laporan tahunan bank umum syariah dari tahun 2014 sampai 2018 yang telah diaudit dan dipublikasikan kepada public melalui website resmi seluruh bank umum syariah di Indonesia serta data statistik perbankan syariah dari situs website OJK (Otoritas Jasa Keuangan). Populasi yang digunakan dalam penelitian ini yaitu seluruh bank umum syariah (BUS) di Indonesia tahun 2014-2018 yang telah terdaftar di OJK. Sedangkan teknik pengambilan sampel dalam penelitian ini yaitu dengan menggunakan metode purposive sampling. Sampel yang diambil dalam penelitian ini adalah 7 (tujuh) bank umum syariah yang memiliki data lengkap dari tahun 2014-2018.

\section{Operasionalisasi Variabel}

Sugiyono (2017, hal. 39) menjelaskan bahwa variabel penelitian adalah suatu atribut atau sifat atau nilai dari orang, obyek atau kegiatan yang mempunyai variasi tertentu yang ditetapkan oleh peneliti untuk dipelajari dan kemudian ditarik kesimpulannya. Variabel dalam penelitian ini dibagi menjadi 2 (dua) bagian yaitu variabel independen dan variabel dependen. Adapun variabel independen dalam penelitian ini yaitu NPF pembiayaan murabahah, NPF pembiayaan mudharabah, dan NPF pembiayaan musyarakah. Sedangkan variabel dependennya adalah profitabilitas. Tabel 2 menjelaskan secara detail tentang operasionalisasi variabel. 
Tabel 2

Operasionalisasi Variabel

\begin{tabular}{|c|c|c|c|c|}
\hline No. & Variabel & Definisi & Indikator & Skala \\
\hline 1 & Profitabilitas & $\begin{array}{l}\text { ROA juga dapat } \\
\text { diartikan sebagai } \\
\text { gambaran } \\
\text { produktivitas bank } \\
\text { dalam mengelola } \\
\text { dana sehingga } \\
\text { menghasilkan } \\
\text { keuntungan } \\
\text { (Sugiono 2009: 80) }\end{array}$ & $R O A=\frac{\text { Laba Bersih }}{\text { Total Aset }}$ & Rasio \\
\hline 2 & $\begin{array}{l}\text { Pembiayaan } \\
\text { Murabahah }\end{array}$ & $\begin{array}{l}\text { Risiko } \\
\text { pembiayaan } \\
\text { murabahah } \\
\text { merupakan risko } \\
\text { yang terjadi } \\
\text { karena faktor } \\
\text { ekonomi yang } \\
\text { melemah dan } \\
\text { tidak mampu } \\
\text { membayar } \\
\text { tagihan }\end{array}$ & $\begin{array}{c}\text { NPF Murabahah= } \\
\frac{\text { Total Pembiayaan Murabahah Bermasalah }}{\text { Total Pembiayaan Murabahah yang disalurkan }}\end{array}$ & Rasio \\
\hline 3 & $\begin{array}{l}\text { Pembiayaan } \\
\text { Mudharabah }\end{array}$ & $\begin{array}{l}\text { Pembiayaan } \\
\text { mudharabah } \\
\text { adalah perjanjian } \\
\text { awal yang telah } \\
\text { disepakati antara } \\
\text { bank sebagai } \\
\text { pemilik modal } \\
\text { dengan } \\
\text { pengusaha. } \\
\text { keuntungan akan } \\
\text { dibagi di akhir } \\
\text { sesuai dengan } \\
\text { kesepakatan awal } \\
\text { serta kerugian } \\
\text { sepenuhnya } \\
\text { ditanggung oleh } \\
\text { bank }\end{array}$ & $\begin{array}{c}\text { NPF Mudharabah }= \\
\frac{\text { Total Pembiayaan Mudharabah Bermasalah }}{\text { Total Pembiayaan Mudharabah yang disalurkan }}\end{array}$ & Rasio \\
\hline 4 & $\begin{array}{l}\text { Pembiayaan } \\
\text { Musyarakah }\end{array}$ & $\begin{array}{l}\text { Pembiayaan } \\
\text { Musyarakah } \\
\text { adalah faktor } \\
\text { yang disebabkan } \\
\text { terjadinya } \\
\text { pembiayaan yang } \\
\text { bermasalah pada } \\
\text { akad musyarakah } \\
\text { (Fauzan, 2012) }\end{array}$ & $\begin{array}{c}\text { NPF Musyarakah= } \\
\frac{\text { Total Pembiayaan Musyarakah Bermasalah }}{\text { Total Pembiayaan Musyarakah yang disalurkan }}\end{array}$ & Rasio \\
\hline
\end{tabular}

\section{Teknik Analisis Data}

Penelitian ini menggunakan regresi data panel sebagai metode analisis data dalam mengestimasi pengaruh Non-Performing Financing (NPF) pembiayaan murabahah, NonPerforming Financing (NPF) pembiayaan mudharabah, dan Non-Performing Financing (NPF) pembiayaan musyarakah terhadap profitabilitas. Tahapan yang harus dilalui dalam analisis regresi data panel adalah: (1) Pemilihan model regresi panel (common effect model, fixed effect model, atau random effect model; (2) Uji asumsi model regresi panel; dan (3) Uji hipotesis. Penelitian ini menggunakan uji Chow test, Hausman test, dan Lagrange Multiplier test (LM test) untuk memilih model regresi terbaik (Ekananda, 2015). Uji Chow test untuk memilih antara common effect model atau fixed effect model. Uji Hausman test untuk memilih fixed effect model atau 
random effect model. LM test untuk menentukan model terbaik antara common effect model atau random effect model. Tingkat signifikansi yang digunakan dalam penelitian ini adalah $5 \%$. Berikut ini adalah model regresi panel dalam penelitian:

$$
Y=\alpha+\beta_{1} X_{1}+\beta_{2} X_{2}+\beta_{3} X_{3}+\varepsilon
$$

Keterangan:

Y : Profitabilitas

$\alpha$ : Konstanta

$\beta$ :Koefisien Regresi

$\mathrm{X}_{1}$ :NPF Pembiayaan Murabahah

$\mathrm{X}_{2}$ : NPF Pembiayaan Mudharabah

$\mathrm{X}_{3}:$ NPF Pembiayaan Musyarakah

$\varepsilon$ : Error

Penelitian ini juga melakukan uji ketangguhan (robustness test) dengan menggunakan proksi profitabilitas yang lain yaitu return on equity (ROE). Uji ini dilakukan untuk melihat apakah hasil regresi panel sensitif terhadap pemilihan proksi profitabilitas atau tidak. Apabila hasil regresi menunjukkan kesimpulan yang sama, berarti model penelitian tidak sensitif terhadap pemilihan proksi profitabilitas.

\section{HASIL DAN PEMBAHASAN}

\section{Statistik Deskriptif}

Statistik deskriptif merupakan proses transformasi data penelitian dalam bentuk tabulasi yang menyajikan ringkasan penyusunan yang dilihat dari nilai rata-rata (mean), standar deviasi, varians, maksimum, dan minimum (Ghozali, 2013). Tabel 3 menyajikan statistik deskriptif dari data penelitian.

Tabel 3

Statistik Deskriptif

\begin{tabular}{lllll}
\hline & ROA & NPF_MRBH & NPF_MDRH & NPF_MSRKH \\
\hline MEAN & $-0,004731$ & 0,078528 & 0,036096 & 0,077566 \\
MEDIAN & 0,002700 & 0,052078 & 0,014234 & 0,049840 \\
MAX & 0,019900 & 0,275977 & 0,214455 & 0,417144 \\
MIN & $-0,107700$ & 0,018672 & 0,000000 & 0,003132 \\
STD. DEV & 0,026141 & 0,064066 & 0,053486 & 0,087109 \\
\hline
\end{tabular}

Sumber: Data Olah EViews

Tabel 3 memperlihatkan bahwa profitabilitas pada bank umum syariah memiliki nilai ratarata sebesar $-0,004731$ atau $-0,47 \%$ selama periode penelitian. Artinya menunjukkan tingkat profitabilitas bank umum syariah masih relatif kecil, disebabkan terjadinya beberapa faktor diantaranya adalah pembiayaan-pembiayaan yang mengandung kredit macet dan kualitas dari pengelolaan aset produktif yang kurang baik. Variabel NPF pembiayaan murabahah memiliki nilai rata-rata sebesar 0,078528 atau $8 \%$, dimana nilai ini di atas standar yang telah ditentukan oleh OJK yaitu pada level 5\%. NPF pembiayaan mudharabah memiliki nilai rata-rata sebesar 0,036096 atau 4\%, hasil ini menunjukkan bahwa nilai NPF pembiayaan pada akad mudharabah ini di bawah standar OJK. Sedangkan nilai NPF pembiayaan musyarakah memiliki nilai rata-rata sebesar 0,077566 atau 8\%, hasil ini menunjukkan bahwa nilai NPF pada akad ini masih tinggi di atas 
standar yang telah ditetapkan oleh OJK dan mengakibatkan kurang baiknya kualitas pembiayaan pada bank tersebut.

\section{Pemilihan Model Regresi Panel}

Hasil Chow test, Hausman test, dan LM test diringkas dalam Tabel 4. Hasil Chow test menyatakan bahwa model regresi panel terbaik untuk dipilih adalah common effect model. Hasil Hausman test menunjukkan bahwa random effect model dipilih sebagai model regresi panel terbaik. Hasil LM test menyatakan bahwa model regresi panel terbaik yang dipilih adalah common effect model. Oleh karena itu, common effect model digunakan untuk mengestimasi data panel.

Tabel 4

Pemilihan Model Terbaik

\begin{tabular}{lcc}
\hline \multicolumn{1}{c}{ Nama Uji } & Probabilitas & Kesimpulan \\
\hline Chow Test & 0,3406 & Common Effect \\
Hausman Test & 0,1134 & Random Effect \\
LM Test & 0,1953 & Common Effect \\
\hline
\end{tabular}

Sumber: Data Olah EViews

\section{Uji Asumsi Klasik}

Karena model terbaik yang dipilih adalah common effect model, maka tahapan berikutnya yaitu uji asumsi klasik, meliputi uji multikolinearitas dan heteroskedastisitas. Penelitian ini menggunakan uji korelasi antar variabel independen untuk menguji ada tidaknya multikolinearitas. Hasil uji korelasi di Tabel 5 menunjukkan bahwa tidak ada korelasi antar variabel independen di atas 0,8 sehingga dapat disimpulkan bahwa tidak terdapat multikolinearitas dalam data penelitian. Uji heteroskedastisitas dilakukan dengan menggunakan uji Glejser. Uji Glejser dilakukan dengan meregresi variabel independen terhadap nilai absolut residual. Tabel 6 menunjukkan bahwa tidak ada variabel independen yang signifikan, maka dapat disimpulkan bahwa model terbebas dari heteroskedastisitas.

Tabel 5

Hasil Uji Korelasi

\begin{tabular}{cccc}
\hline Variabel & NPF_MRBH & NPF_MDRH & NPF_MSRKH \\
\hline NPF_MRBH & 1,000000 & 0,007196 & 0,448346 \\
NPF_MDRH & 0,007196 & 1,000000 & 0,180084 \\
NPF_MSRKH & 0,448346 & 0,180084 & 1,000000 \\
\hline
\end{tabular}

Sumber: Data Olah EViews

Tabel 6

Hasil Uji Glejser

\begin{tabular}{ccccc}
\hline Variabel & Koefisien & Std. Error & t-Statistic & Prob. \\
\hline C & 0,017031 & 0,008116 & 2,098433 & 0,0441 \\
NPF_MRBH & 0,104167 & 0,082357 & 1,264821 & 0,2871 \\
NPF_MDRH & $-0,101093$ & 0,089644 & $-1,127716$ & 0,2681 \\
NPF_MSRKH & $-0,083904$ & 0,061577 & $-1,362602$ & 0,1828 \\
\hline
\end{tabular}

Sumber: Data Olah EViews 


\section{Hasil Uji Hipotesis}

Tabel 7

Hasil Regresi Data Panel

\begin{tabular}{ccccc}
\hline Variabel & Koefisien & Std. Error & t-Statistic & Prob. \\
\hline C & 0,021948 & 0,005138 & 4,271609 & 0,0002 \\
NPF_MRBH & $-0,131646$ & 0,052139 & $-2,524931$ & 0,0169 \\
NPF_MDRH & $-0,182835$ & 0,056752 & $-3,221676$ & 0,0030 \\
NPF_MSRKH & $-0,125600$ & 0,038983 & $-3,221914$ & 0,0030 \\
\hline R-squared & 0,598413 & & & \\
Prob(F-statistic) & 0,000003 & & & \\
\hline
\end{tabular}

Sumber: Data Olah EViews

Persamaan regresi yang diperoleh dari hasil regresi panel yang tertera pada Tabel yaitu adalah sebagai berikut:

\section{$\mathrm{Y}=0,021948-0,131646 \mathrm{MRBH}-0,182835 \mathrm{MDRH}-0,125600 \mathrm{MSRKH}$}

Dari persamaan tersebut dapat dijelaskan bahwa konstanta sebesar 0,021948 diartikan sebagai tingkat profitabilitas ketika variabel independen yaitu NPF pembiayaan murabahah, NPF pembiayaan mudharabah, dan NPF pembiayaan musyarakah adalah 0 . Nilai koefisien regresi sebesar -0,131646 menunjukkan nilai NPF murabahah memiliki arah regresi negatif, dimana setiap peningkatan sebesar 1 (satu) persen NPF murabahah akan menurunkan tingkat profitabilitas sebesar 0,131646 persen. Nilai koefisien regresi sebesar -0,182835 menunjukkan nilai NPF mudharabah memiliki arah regresi negatif, dimana setiap peningkatan 1 (satu) persen NPF mudharabah akan menurunkan tingkat profitabilitas sebesar 0,131646. Nilai koefisien regresi sebesar -0,125600 menunjukkan nilai NPF musyarakah memiliki arah regresi negatif, dimana setiap peningkatan 1 (satu) persen NPF musyarakah akan menurunkan tingkat profitabilitas sebesar 0,125600 .

Nilai $\mathbf{R}^{2}$ pada hasil regresi data panel sebesar 0,5984. Hal ini menunjukkan bahwa kontribusi seluruh variabel independen dalam menjelaskan variabel dependen sebesar 59,84\% dan sisanya sebesar 40,16\% yang dijelaskan oleh variabel lain di luar model penelitian. Nilai probabilitas dari F-statistic lebih kecil dari tingkat signifikansi yang ditetapkan (5\%), maka dapat disimpulkan bahwa NPF murabahah, NPF mudharabah, dan NPF musyarakah secara bersama-sama berpengaruh terhadap profitabilitas bank umum syariah di Indonesia.

\section{Pengaruh NPF Pembiayaan Murabahah Terhadap Profitabilitas}

Tabel 7 menunjukkan bahwa nilai koefisien regresi NPF pembiayaan murabahah sebesar 0,131646 dan nilai probabilitasnya sebesar 0,0169 lebih kecil dari tingkat signifikansi. Hasil ini menunjukkan bahwa NPF pembiayaan murabahah berpengaruh negatif dan signifikan terhadap profitabilitas bank umum syariah di Indonesia.

Hasil penelitian ini tidak sejalan dengan penelitian yang dilakukan oleh Widya dkk (2015) yang menyatakan bahwa NPF pembiayaan murabahah tidak berpengaruh signifikan terhadap profitabilitas. Hasil pengujian pada variabel ini menjelaskan bahwa NPF pembiayaan pada akad murabahah berpengaruh terhadap profitabilitas bank umum syariah, sehingga menyebabkan penurunan pada tingkat profitabilitas pada bank umum syariah di Indonesia. Hal ini sesuai dengan teori yang menyatakan bahwa semakin tinggi NPF pembiayaan maka semakin menurun tingkat profitabilitas. Produk pembiayaan murabahah ini merupakan pembiayaan yang paling sering digunakan oleh masyarakat dalam pengaplikasiannya. 


\section{Pengaruh NPF Pembiayaan Mudharabah Terhadap Profitabilitas}

Nilai koefisien regresi NPF pembiayaan mudharabah pada Tabel 7 sebesar -0,182835 dan nilai probabilitasnya sebesar 0,0030. Hasil ini membuktikan bahwa NPF pembiayaan mudharabah berpengaruh negatif dan signifikan terhadap profitabilitas bank umum syariah di Indonesia.

Hasil penelitian ini sejalan dengan penelitian yang dilakukan oleh Hadiyati (2013) yang menyatakan bahwa NPF pembiayaan mudharabah berpengaruh negatif dan signifikan terhadap profitabilitas. NPF pembiayaan pada akad mudharabah akan berpengaruh kepada para investor (shohibul maa) yang menanamkan modalnya di perbankan syariah. Hal ini menjadi perhatian perbankan syariah pada produk pembiayaan mudharabah ini, karena para pemilik modal akan melihat performa dan peluang pada produk pembiayaan tersebut. Kelemahan dari pembiayaan akad mudharabah adalah bank sebagai pengelola dana yang akan menanggung kerugian apabila terjadi kerugian di dalam investasi atau dengan kata lain kerugian ditanggung sepihak dan ini tertera di dalam perjanjian akad mudharabah.

\section{Pengaruh NPF Pembiayaan Musyarakah Terhadap Profitabilitas}

Nilai koefisien regresi NPF pembiayaan musyarakah pada Tabel 7 sebesar -0,125600 dan nilai probabilitasnya sebesar 0,0030. Hasil ini membuktikan bahwa NPF pembiayaan musyarakah berpengaruh negatif dan signifikan terhadap profitabilitas bank umum syariah di Indonesia.

Hasil penelitian ini tidak sejalan Yulianah dan Komariah (2017) yang menyatakan bahwa NPF pembiayaan musyarakah tidak berpengaruh terhadap profitabilitas. NPF pembiayaan musyarakah ini memiliki pengaruh terhadap profitabilitas sama halnya dengan NPF pembiayaan mudharabah. Hasil ini menunjukkan bahwa hubungan yang terjadi antara NPF pembiayaan musyarakah dengan profitabilitas adalah berlawanan. Artinya setiap ada peningkatan atau pada NPF pembiayaan musyarakah maka profitabilitas bank umum syariah akan mengalami penurunan.

\section{Uji Ketangguhan (Robustness Test)}

Hasil dari uji ketangguhan pada Tabel 8 menunjukkan bahwa seluruh variabel independen yaitu NPF pembiayaan murabahah, NPF pembiayaan mudharabah, dan NPF pembiayaan musyarakah memiliki pengaruh negatif dan signifikan terhadap profitabilitas (ROE). Artinya bahwa hasil regresi ini konsisten dengan hasil regresi sebelumnya walaupun proksi profitabilitasnya menggunakan ROE.

Tabel 8

Uji Ketangguhan (Robustness Test)

\begin{tabular}{ccccc}
\hline Variabel & Koefisien & Std. Error & t-Statistic & Prob. \\
\hline C & 0,163916 & 0,043347 & 3,781435 & 0,0007 \\
NPF_MRBH & $-0,956173$ & 0,439856 & $-2,173831$ & 0,0375 \\
NPF_MDRH & $-1,415029$ & 0,478773 & $-2,955532$ & 0,0059 \\
NPF_MSRKH & $-1,054815$ & 0,328872 & $-3,207375$ & 0,0031 \\
R-squared & 0,566674 & & & \\
Prob(F-statistic) & 0,000008 & & & \\
\hline
\end{tabular}

Sumber: Data Olah Eviews (Diolah Penulis) 


\section{KESIMPULAN}

Hasil penelitian menyimpulkan bahwa secara parsial NPF pembiayaan murabahah, NPF pembiayaan mudharabah, dan NPF pembiayaan musyarakah masing-masing berpengaruh negatif dan signifikan terhadap profitabilitas. Hasil ini tangguh (robust) terhadap penggunaan proksi profitabilitas yang lain yaitu ROE. Hasil penelitian menunjukkan bahwa adanya pengaruh pembiayaan bermasalah atau terjadinya kredit macet dalam pembiayaan bank umum syariah yang berdampak pada profitabilitas bank umum syariah di Indonesia. Oleh karena itu, perbankan syariah harus lebih memperhatikan produk pembiayaan-pembiayaannya dengan meningkatkan kualitas pembiayaan tersebut dan meminimalisir seminimal mungkin terjadinya pembiayaan bermasalah, serta memperbaiki dan mengembangkan investasi yang dilakukan bank di dalam sektor yang lebih luas lagi berdasarkan prinsip syariah dan asas kepercayaan yang ditanamkan oleh bank terhadap nasabah sehingga bank dapat mengelola dana para nasabahnya dengan lebih baik lagi.

\section{DAFTAR PUSTAKA}

Arifin, Z. (2012). Dasar-Dasar Manajemen Bank Syariah (Cetakan Ke-Tujuh). Jakarta: Azkia Publisher.

Aryani, Y., Anggraeni, L., \& Wiliasih, R. (2016). Faktor-Faktor yang Mempengaruhi NonPerforming Financing pada Bank Umum Syariah Indonesia Periode 2010-2014. Jurnal AlMuzara'ah, 4 (1).

Ekananda, M. (2015). Analisis Ekonometrika Data Panel. Jakarta: Mitra Wacana Media.

Fauzan., Muhammad, A. (2012). Pengaruh Tingkat Risiko Pembiayaan Musyarakah dan Pembiayaan Murabahah Terhadap Tingkat Profitabilitas Bank Syariah (Studi Pada Bank Aceh Syariah Cabang Banda Aceh). Jurnal Akuntansi Pascasarjana Universitas Syiah Kuala. Volume 2, 76-85.

Ghozali, I. (2013). Aplikasi Analisis Multivariate dengan Program IBM SPSS 21. Semarang: Badan Penerbit Universitas Diponegoro.

Gitman, J Lawrence. (2009). Principle of Managerial Finance (12 th Edition). New York: Person International. Prentice hall.

Hadiyati P, \& Riski, A. B. (2013). Pengaruh Non-Performing Financing Pembiayaan Mudharabah dan Musyarakah Pada Bank Muamalat Indonesia. e-Jurnal Manajemen dan Bisnis. 1(1), 114.

Huriyah, L. (2014). Manajemen Keuangan. Jakarta: SAP.

Hutami, K. (2010). Pengaruh Tingkat Risiko Pembiayaan Musyarakah dan Pembiayaan Murabahah Terhadap Tingkat Profitabilitas Bank Syariah.

Ikatan Bankir Indonesia. (2018). Memahami Bisnis Bank Syariah (Cetakan Ketiga). Jakarta: PT. Gramedia Pustaka Utama.

Irham, F. (2013). Pengantar Manajemen Keuangan Teori dan SoalJawab (Cetakan Kedua). Bandung: Alfabeta.

Karim, A. A. (2014). Analisis Fiqih dan Keuangan (Edisi Kelima). Jakarta: Raja Grafindo Mudrajad., \& Suhardjono. (2011). Manajemen Perbankan (Edisi Kesatu). Yogyakarta: UPP AMP YKPN.

Muhamad. (2015). Manajemen Dana Bank Syariah (Cetakan Kedua). Jakarta: Raja Grafindo.

Muhamad. (2018). Manajemen Bank Syariah (Edisi Kedua). Yogyakarta: UPP STIM YKPN.

Nurhayati, S., \& Wasilah. (2013). Akuntansi Syariah Di Indonesia (Edisi Keempat). Jakarta: Salemba Empat.

Otoritas Jasa Keuangan. (2018). Statistik Perbankan Syariah. https://ojk.go.id/id/kanal/syariah/data-dan-statistik/statistik-perbankan syariah/

Prabowo, B. A. (2012). Aspek Hukum Pembiayaan Murabahah Pada Perbankan Syari'ah. Yogyakarta: UII Press. 
Puji, H., \& Riski, A. B. (2013). Pengaruh NPF Pembiayaan Mudharabah dan Musyarakah pada Bank Muamalat Indonesia. e-jurnal Manajemen dan Bisnis, 1 (1).

Rifqi, M. (2010). Akuntansi Keuangan Syariah, Konsep dan Implementasi PSAK Syariah (Edisi Kedua). Yogyakarta: P3EI Press.

Sudiyatno, B. \& Suroso. (2010). Analisis Pengaruh Dana Pihak Ketiga, BOPO, CAR, LDR Terhadap Kinerja Keuangan Pada Sektor Perbankan yang Go Public Di Bursa Efek Indonesia. Jurnal Ilmiah. Semarang: Universitas Stikubank.

Sugiono, A. (2009). Manajemen Keuangan untuk Praktisi Keuangan. Jakarta: Grasindo Sugiyono. (2017). Metodologi Penelitian Kuantitatif, Kualitatif dan R\&D. Bandung: Alfabeta. Suryani. (2011). Analisis Pengaruh Financing to Deposit Ratio (FDR) terhadap Profitabilitas Perbankan Syariah di Indonesia. Jurnal Walisongo Volume 19, Nomor 1, Mei 2011, 55 Undang-Undang No. 10 Tahun 1998 Tentang Perbankan.

Yulianah, \& Komariah, E. (2017). Risiko Pembiayaan Murabahah, Mudharabah dan Musyarakah BUS Terhadap Profitabilitas (ROA) Periode 2011-2015. PROFITA Akademi Akuntansi Bina Insani, 10 (1)

Widya et al. (2015). Analisis Pengaruh Non-Performing Financing Pembiayaan Murabahah, Mudharabah, dan Musyarakah Terhadap Profitabilitas pada Bank Umum Syariah. Jurnal Manajemen Fakultas Ekonomi Universitas Jember (UNEJ). 